\title{
THE DEAD SPACE AFTER ADDITION OF OXYGEN AND PREMEDICATION WITH NARCOTICS AND BELLADONNA DRUGS
}

\author{
K.W. TuhnBull, B.A.sc., M.D."
}

IT Is kNown that physiological dead space $\left(\mathrm{V}_{\mathrm{p}}{ }^{\mathrm{PHYs}}\right)$ and dead space/tidal volume ratio $\left(V_{D} / V_{T}\right)$ increase when anaesthesia is induced ${ }^{1,2}$ while a further increase occurs when ventilation is controlled ${ }^{1,3}$ or end-expiratory pressure added. ${ }^{4}$ A recent publication ${ }^{5}$ shows that added oxygen increases the alveolar compartment dead space. Other studies ${ }^{0,7}$ have shown that premedication with atropine, scopolamine or morphine also will change dead space. The present paper reports the effects on dead space of an increase in inspired oxygen after combinations of narcotics and belladonna drugs.

\section{METHODS}

The studies were performed on 15 patients, varying in age from 30 to 64 ycars, undergoing operations for coronary artery vein bypass grafts and for aortic or mitral valve replacement. These patients were selected because the sampling lines were inserted for monitoring purposes prior to induction of anaesthesia. Measurements were made 24 hours pre-operatively, and on the day of operation 60 minutes after intramuscular premedication with morphine $0.15 \mathrm{mg} / \mathrm{kg}$ and either scopolamine $0.4-0.6 \mathrm{mg}$ or atropine $0.6 \mathrm{mg}$, or else meperidine $1.5 \mathrm{mg} / \mathrm{kg}$ with atropine $0.6 \mathrm{mg}$.

End-tidal and mixed expired gas samples were obtained using a Rahn-Otis endtidal sampler, 15 litre rubber bags and a Beckman micro-catheter sample pump. Analysis was continuous using a Beckman $\mathrm{CO}_{2}$ analyzer and a Beckman Oxygen Analyzer, connected in series. Precalibration of these meters was done prior to each set of measurements using gases pre-calibrated by the Scholander method. Tidal volumes and respiratory rates were measured using a Collins 9 litre spirometer and compared to values obtained with a Wright respirometer and a precalibrated rotameter.

The first set of measurements was done on supine patients breathing room air after the end-tidal $\mathrm{PCO}_{2}$ had been constant for $10-15$ minutes. The patients were then given 100 per cent oxygen and another set of measurements was done 10 to 15 minutes later. Arterial blood samples were taken preoperatively via radial artery puncture using heparinized glass syringes. The same protocol was repeated when arterial and superior vena caval blood samples were taken one hour after premedication. End-tidal and mixed expired gases were sampled from the endtidal sampler and the baffled rubber bag.

Blood gas tensions and $\mathrm{pH}$ were measured with a Radiometer $\mathrm{pH} /$ blood gas

\footnotetext{
•Clinical Research Fellow (Pulmonary Diseases), St. Paul's Hospital, Vancouver, British Columbia.
}

486

Canad. Anaesth. Soc. J., vol, 19, no, 5, September 1972 
monitor and microelectrode unit at 37 degrees Centigrade. Calibration of this apparatus was made before and after each set of determinations. Corrections to body temperature were made where necessary.

Dead space/tidal volume ratios were calculated using the Riley ${ }^{8}$ modification of the Bohr equation substituting arterial $\mathrm{Pco}_{2}$ for "ideal" alveolar Pco.. All statistical evaluations were based on the "student t-test" (paired two-tail t-tests).

\section{REsults}

Analysis of the results shown in Tables I, II and III shows adequate arterial oxygenation in all patients breathing room air (inspired $\mathrm{O}_{2}$ of 20.95 per cent) with a mean $\mathrm{PaO}_{2}$ of $90.8 \mathrm{~mm} \mathrm{Hg}$ preoperatively and $94.0 \mathrm{~mm} \mathrm{Hg}$ after premedication. When the inspired oxygen was changed to 100 per cent in the preoperative period, there was a significant increase in dead space/tidal volume ratio $\left(\mathrm{V}_{\mathrm{D}} / \mathrm{V}_{\mathrm{T}}\right)$ and a significant increase in physiological dead space $\left(\mathrm{V}_{\mathrm{D}}^{\mathrm{PHYS}}\right)$.

TABLE I

Effects of Increasing Alveolar Oxygen Concentration Before Premedication in 15 Patients

\begin{tabular}{|c|c|c|c|c|c|c|c|}
\hline & $\begin{array}{c}\mathrm{P}_{\mathrm{A}} \mathrm{O}_{2} \\
\text { m⿻ } \mathrm{Hg}\end{array}$ & $\begin{array}{l}\dot{\mathrm{V}} \mathrm{CO}_{2} \\
\text { ml stpd }\end{array}$ & $\begin{array}{l}\mathrm{V}_{\mathrm{D}}^{\mathrm{PHYS}} \\
\mathrm{mlBTPS}\end{array}$ & $\mathrm{ml} \mathrm{V}_{\mathrm{T}}$ & $\underset{\%}{\mathrm{~V}_{\mathbf{n}} / \mathrm{V}_{\mathbf{r}}}$ & $\begin{array}{l}\mathrm{PaCO}_{2} \\
\mathrm{~mm} \mathrm{Hg}\end{array}$ & $\begin{array}{c}\mathrm{PaO}_{2} \\
\mathrm{~mm} \mathrm{Hg}\end{array}$ \\
\hline $\begin{array}{l}\text { mean } \\
\text { (sd) }\end{array}$ & $\begin{array}{r}112.7 \\
\quad(3.66)\end{array}$ & $\begin{array}{l}170.1 \\
(11.5)\end{array}$ & $\begin{array}{l}268.9 \\
(47.9)\end{array}$ & $\begin{array}{l}699.9 \\
(80.1)\end{array}$ & $\begin{array}{l}36.5 \\
(2.2)\end{array}$ & $\begin{array}{l}34.2 \\
(1.52)\end{array}$ & $\begin{array}{l}90.8 \\
(2.84)\end{array}$ \\
\hline $\begin{array}{l}\text { mean } \\
\text { (sd) }\end{array}$ & $\begin{array}{l}652.5 \\
(10.3)\end{array}$ & $\begin{array}{l}168.0 \\
(13.2)\end{array}$ & $\begin{array}{l}351.3 \\
(39.1)\end{array}$ & $\begin{array}{l}738.7 \\
(77.7)\end{array}$ & $\begin{array}{l}45.8 \\
(2.2)\end{array}$ & $\begin{array}{l}34.9 \\
(1.45)\end{array}$ & $\begin{array}{l}492,0 \\
(20.7)\end{array}$ \\
\hline $\mathbf{P}$ & 0.01 & NS & 0.01 & 0.01 & 0.01 & NS & 0.01 \\
\hline
\end{tabular}

TABLE II

Effect of Increasing Alveolar Oxygen Concentrations after Premedication in 15 Patients

\begin{tabular}{|c|c|c|c|c|c|c|c|}
\hline & $\underset{\mathrm{mm} \mathrm{Hg}}{\mathrm{P}_{\mathbf{A}} \mathrm{O}_{2}}$ & $\begin{array}{l}\dot{V} \mathrm{CO}_{z} \\
\mathrm{ml} \text { stpd }\end{array}$ & $\begin{array}{l}\mathrm{V}_{\mathrm{D}}^{\text {PHYg }} \\
\mathrm{ml} \text { BTPS }\end{array}$ & $\begin{array}{c}V_{T} \\
m l \text { BTPS }\end{array}$ & $\begin{array}{c}\mathrm{V}_{\mathrm{D}} / \mathrm{V}_{\mathrm{T}} \\
\mathrm{F}_{0}\end{array}$ & $\begin{array}{l}\mathrm{PaCO}_{2} \\
\mathrm{~mm} \mathrm{Hg}_{\mathrm{g}}\end{array}$ & $\underset{\mathrm{mm} \mathrm{H}}{\mathrm{PaO}_{\mathrm{g}}}$ \\
\hline $\begin{array}{l}\text { mean } \\
\text { (sd) }\end{array}$ & $\begin{array}{l}112.7 \\
(2.78)\end{array}$ & $\begin{array}{c}160.0 \\
(8.25)\end{array}$ & $\begin{array}{r}207.9 \\
(24,2)\end{array}$ & $\begin{array}{c}600.7 \\
(58.9)\end{array}$ & $\begin{array}{l}36.1 \\
(2.6)\end{array}$ & $\begin{array}{l}38.4 \\
(1.10)\end{array}$ & $\begin{array}{l}94.0 \\
(2.56)\end{array}$ \\
\hline $\begin{array}{l}\text { mean } \\
\text { (sid) }\end{array}$ & $\begin{array}{r}634.1 \\
(9.25)\end{array}$ & $\begin{array}{r}141 \\
(8.90)\end{array}$ & $\begin{array}{l}264.4 \\
(70.3)\end{array}$ & $\begin{array}{l}581.7 \\
(43.0)\end{array}$ & $\begin{array}{l}45.7 \\
(3.0)\end{array}$ & $\begin{array}{l}39.4 \\
(1.04)\end{array}$ & $\begin{array}{l}466.0 \\
(24.0)\end{array}$ \\
\hline $\mathbf{P}$ & 0.01 & 0.01 & 0.01 & NS & 0.01 & NS & 0.01 \\
\hline
\end{tabular}

After premedication there was a significant increase in $V_{D} / V_{T}$ on 100 per cent oxygen and $\mathrm{V}_{\mathrm{D}}{ }^{\mathrm{PH}} \mathrm{rS}$ increased. The $\mathrm{V}_{\mathrm{D}} / \mathrm{V}_{\mathrm{T}}$ ratios were comparable in magnitude before and after premedication. Carbon dioxide output $\left(\mathrm{V}_{\mathrm{V}} \mathrm{CO}_{2}\right)$ decreased with premedication while arterial carbon dioxide tensions $\left(\mathrm{PaCO}_{2}\right)$ were normal in the premedicated patient and significantly decreased in them preoperatively. Large tidal volumes $\left(V_{T}\right)$ were the rule in this study.

\section{Discussion}

Changes in dead space $\left(V_{D}{ }^{\text {PHrs }}\right)$ and dead space/tidal volume ratios $\left(V_{D} / V_{T}\right)$ in this study were a function of inspired oxygen concentration, premedication 
TABLE III

Comparison of Measurements Made Before and After Premedication at Low and High Alveolar Oxygen Levels

\begin{tabular}{|c|c|c|c|c|c|c|c|c|}
\hline & & $\underset{\mathrm{mm} \mathrm{H}_{\mathrm{g}}}{\mathrm{P}_{\mathrm{A}} \mathrm{O}_{2}}$ & $\begin{array}{l}\dot{\mathrm{V}} \mathrm{CO}_{\mathrm{g}} \\
\text { ml stpd }\end{array}$ & $\begin{array}{l}\mathrm{V}_{\mathrm{D}}^{\mathrm{PHYg}} \\
\text { ml BTPS }\end{array}$ & $\frac{V_{\mathrm{I}}}{\mathrm{ml} \mathrm{B} \text { TPS }}$ & $\mathrm{V}_{\mathrm{D} / \mathrm{T}}$ & $\begin{array}{l}\mathrm{PaCO}_{2} \\
\mathrm{~mm} \mathrm{Hg}\end{array}$ & $\underset{\mathrm{mm} \mathrm{Hg}}{\mathrm{PaO}_{2}}$ \\
\hline \multirow[t]{2}{*}{ (a) } & $\begin{array}{l}20.95 \% \text { oxygen } \\
\text { i. before } \\
\text { mean } \\
\text { (sd) }\end{array}$ & $\begin{array}{c}112.7 \\
(3.66)\end{array}$ & $\begin{array}{l}170.1 \\
(11.5)\end{array}$ & $\begin{array}{l}268.9 \\
(47.9)\end{array}$ & $\begin{array}{l}699.0 \\
(80.1)\end{array}$ & $\begin{array}{l}36.5 \\
(2.5)\end{array}$ & $\begin{array}{l}34.2 \\
(1.52)\end{array}$ & $\begin{array}{l}90.8 \\
(2.84)\end{array}$ \\
\hline & $\begin{array}{l}\text { mean } \\
\text { (sd) } \\
\stackrel{P}{P}\end{array}$ & $\begin{array}{c}112.7 \\
(2.78) \\
\text { NS }\end{array}$ & $\begin{array}{c}160.0 \\
(8.25) \\
0.05\end{array}$ & $\begin{array}{r}207.9 \\
(24.2) \\
0.01\end{array}$ & $\begin{array}{c}600.7 \\
(58.9) \\
0.01\end{array}$ & $\begin{array}{c}36.1 \\
(2.6) \\
\text { NS }\end{array}$ & $\begin{array}{l}38.4 \\
(1.10) \\
0.01\end{array}$ & $\begin{array}{l}94.0 \\
(2.56) \\
0.01\end{array}$ \\
\hline \multirow[t]{2}{*}{ (b) } & $\begin{array}{l}100 \% \text { oxygen } \\
\text { i. before } \\
\text { mean } \\
\text { (sd) }\end{array}$ & $\begin{array}{l}652.5 \\
(10.3)\end{array}$ & $\begin{array}{l}168.0 \\
(13.2)\end{array}$ & $\begin{array}{l}351.2 \\
(39.1)\end{array}$ & $\begin{array}{l}738.7 \\
(77.7)\end{array}$ & $\begin{array}{l}45.8 \\
(2.2)\end{array}$ & $\begin{array}{l}34.9 \\
(1.45)\end{array}$ & $\begin{array}{l}492.0 \\
(20.7)\end{array}$ \\
\hline & $\begin{array}{l}\text { 11. arter } \\
\text { mean } \\
\text { (sd) } \\
P\end{array}$ & $\begin{array}{c}634.1 \\
(9.25) \\
0.01\end{array}$ & $\begin{array}{r}141.0 \\
(8.9) \\
0.01\end{array}$ & $\begin{array}{r}264.4 \\
(70.3) \\
0.01\end{array}$ & $\begin{array}{r}581.7 \\
(43.0) \\
0.01\end{array}$ & $\begin{array}{l}45.7 \\
\text { (3.0) } \\
\text { NS }\end{array}$ & $\begin{array}{c}39.4 \\
(1.04) \\
0.01\end{array}$ & $\begin{array}{l}466.0 \\
(24) \\
0.01\end{array}$ \\
\hline
\end{tabular}

and large tidal volumes. The increase in $\mathrm{V}_{\mathrm{D}}{ }^{\mathrm{PHYS}}$ and $\mathrm{V}_{\mathrm{D}} / \mathrm{V}_{\mathrm{T}}$ seen with the changes in inspired oxygen from 20.95 per cent to 100 per cent parallel those found when oxygen concentration is increased during anaesthesia ${ }^{5}$ or in normal unanaesthetized individuals. ${ }^{9} V_{D} / V_{T}$ ratios were not significantly altered by the addition of premedication. Since atropine and scopolamine are likely to change ventilation-perfusion ratios secondary to the changes in airway resistance and anatomical dead space which they cause, ${ }^{6.7}$ one would also expect significant physiological dead space changes. However, the decrease in tidal volumes after premedication exhibited in this study could counteract any effect of the premedication on bronchiolar length and diameter. This corresponds to Stephen' ${ }^{10}$ findings using combined scopolamine and secobarbital premedication where addition of the secobarbital resulted in a decreased tidal volume and decreased dead space.

The large tidal volumes did result in large values for $\mathrm{V}_{\mathrm{D}}{ }^{\mathrm{PHYS}}$ as suggested by Askrog. ${ }^{11}$ Premedication moderately decreased the tidal volumes and carbon dioxide excretion thus resulting in smaller absolute values of $\mathrm{V}_{\mathrm{D}}{ }^{\text {PHYS }}$. These results re-emphasize that consideration of the $\mathrm{V}_{\mathrm{D}} / \mathrm{V}_{\mathrm{r}}$ ratio, as advocated recently by Nunn ${ }_{r}^{12}$ is the most practical approach to evaluation of dead space and tidal volume changes.

The mechanism of increase in dead space when breathing 100 per cent oxygen probably involves an increase in alveolar dead space." Sykes ${ }^{5}$ has recently suggested redistribution of pulmonary blood flow due to relaxation of vascular tone or reduction in cardiac output are likely factors. The resultant redistribution of flow would yield increased dead space secondary to a relative under-perfusion of ventilated alveoli. Further studies including pulmonary artery pressures should help to clarify this. The markedly increased alveolar-arterial gradients with 100 per cent oxygen seen in the present study are added support for this hypothesis, as they suggest relative under-perfusion of a number of alveoli. 


\section{Conclusions}

There is a significant increase in dead space/tidal volume ratio $\left(V_{D} / V_{T}\right)$ in patients when the inspired oxygen is increased from 20.95 per cent to 100 per cent. Combined narcotic and belladonna premedication does not significantly affect the $V_{D} / V_{T}$ ratio when the inspired oxygen concentrations are varied. Absolute values of $V_{D}{ }^{\text {PHYS }}$ are increased by high tidal volumes and this should be correlated with the $V_{D} / V_{T}$ changes to aid in the clinical interpretation. Narcoticbelladonna premedication does not contribute to the increase in dead space which is found in the anaesthetized patient.

\section{SUMMARY}

Fifteen patients ranging in age from 30 to 64 years and undergoing cardiac surgery were studied preoperatively and after premedication to assess the effects of narcotic-belladonna premedication on changes in physiological dead space $\left(V_{\mathrm{D}}{ }^{\mathrm{PHYS}}\right)$, when inspired oxygen was varied from 20.95 per cent to 100 per cent. Measurements of arterial blood gases, end-tidal and mixed expired gases showed that there was a significant increase in dead space/tidal volume ratio $\left(\mathrm{V}_{\mathrm{D}} / \mathrm{V}_{\mathrm{T}}\right)$ when the inspired oxygen concentration was increased. Combined narcotic and belladonna premedication did not significantly affect $V_{D} / V_{T}$ ratios when the same increase in inspired oxygen occurred.

Absolute values of $\mathrm{V}_{\mathrm{D}}{ }^{\mathrm{PHYS}}$ are increased by high tidal volumes and this should be correlated with the $V_{D} / V_{T}$ changes to aid in the clinical interpretation. It is likely that narcotic-belladonna premedication does not contribute to the increase in dead space which is sound in the anaesthetized patient.

\section{RÉSUMÉ}

Nous avons étudié 15 malades dont l'âge variait de 30 à 64 ans, malades qui devaient être soumis à la chirurgie cardiaque; l'étude avant l'opération et après la prémédication visait à évaluer les effets de la prémédication avec des narcotiques et de la belladone sur les changements de l'espace mort physiologique $\left(\mathrm{V}_{\mathrm{D}}{ }^{\mathrm{PHYS}}\right)$ alors que l'oxygène inspiré pouvait varier de 20.95 pour cent à 100 pour cent. L'étude des gaz artériels, des gaz expirés et des gaz de la fin de l'air courant a montré qu'il se produisait une augmentation significative de la relation: espace mort/air courant dे mesure que nous augmentions la concentration en oxygène de l'atmosphère inspirée. La prémédication composée de l'association narcotiques et belladone n'a pas modifié de façon significative la relation $V_{D} / V_{T}$ à l'usage d'un taux égal d'oxygène dans l'air inspiré.

Les données absolues $\mathrm{V}_{\mathrm{D}}{ }^{\mathrm{PHYS}}$ sont augmentées par de grands volumes d'air courant et ceci doit être en corrélation avec les changements $V_{\mathrm{D}} / \mathrm{V}_{\mathrm{T}}$ pour aider a linterprétation clinique. Selon toute vraisemblance, la prémédication narcotique/belladone ne prend pas part à l'augmentation de l'espace mort que lon observe chez le sujet sous anesthésie. 


\section{REFERENCES}

1. Campreze, E.J.M., NunN, J.F., \& Pecketr, B.W. A comparison of artificial ventilation and spontaneous respiration with particular reference to ventilation-blood-flow relationships. Brit. J. Anaes. 30: 166 (1958).

2. Thonnton, J.A. Physiological dead space. Changes during general anaesthesia. Anaesthesia 15: 381 (1960).

3. Manshall, B.E. \& Grange, R.A. Changes in respiratory physiology during ether/air anaesthesia. Brit. J. Anaes. $38: 329$ ( 1966 ).

4. Sykes, M.K., Abams, A.P., FinLay, W.F. McConmick, P.W. \& Economides, A. The effects of variations in end-expiratory inflation pressure on cardiorespiratory function in normovolaemic, hypovolaemic and hypervolaemic dogs. Brit. J. Anaes, 42: 669 (1970).

5. Sykes, M.K. \& FinL.AY, W.E.T. Dead space during anaesthesia. Anaesthesia 26: 22 (1971).

6. SMIth, T.C., Stephen, G.W., Zeicer, L., \& Wollman, H. Effects of premedicant drugs on respiration and gas exchange in man. Anesthesiology 28: 883 (1967).

7. Sмгт, T.C. DuBois, A. The effects of scopolamine on the airways of man. Anesthesio$\operatorname{logy} 30: 12(1969)$.

8. Rurey, R.L., L.mmenthal, J.L., Prommer, D.D., Franke, R.E. On the determination of the physiologically effective pressures of oxygen and carbon dioxide in alveolar air. Am. J. Physiol. 147: 191 (1946).

9. Laison, C.P. Jn. \& Severinghaus, I.W. Postural variations in dead space and $\mathrm{CO}_{2}$ gradients breathing air and $\mathrm{O}_{2 .} \mathrm{J}$. Appl. Physiol. 17; 417 (1962).

10. Stephen, G.W., Banner, M.P., Wollman, H., Smith, T.C. Respiratory pharmacology of mixtures of scopolamine with secobarbital and with fentanyl. Anesthesiology 31: 237 (1969).

11. Askroc, V.F., Pender, J.W., SMith, T.C., \& Eckenhoff, J.E. Changes in respiratory dead space during halothane, cyclopropane and nitrous oxide anesthesia. Anesthesiology 25: 3420 (1964).

12. NunN, J.F. Applied respiratory physiology. 1st ed. Landon: Butterworths (1969), Pp. 192 